\title{
THE DETERMINANT FACTORS ON THE MOVEMENT OF SHARIA STOCK IN INDONESIA
}

\author{
Rachmania Nurul Fitri Amijaya ${ }^{1 *}$, Mohammad Yusron Sholikhin $^{2}$, Azizah Esti Pratiwi $^{3}$ \\ *Corresponding Author \\ ${ }^{1}$ Department of Islamic Economics, Faculty of Economic and Business, Universitas Airlangga, Surabaya, Indonesia. \\ rachmania.nurul.fitri-2018@pasca.unair.ac.id. \\ ${ }^{2}$ Department of Islamic Economics, Faculty of Economic and Business, Universitas Airlangga, Surabaya, Indonesia. \\ ${ }^{3}$ Department of Islamic Economics, Faculty of Economic and Business, Universitas Airlangga, Surabaya, Indonesia.
}

\begin{abstract}
This study aims to examine the determinant factors that influence Islamic stocks, JII. The development of the global economy will have an impact on economic turnover in Indonesia. This condition leads to sharing prices will be affected by the global economy. Strengthening in various sectors is needed so that JII stability can be maintained. This study uses quantitative methods with the Vector Error Correction Model (VECM) analysis which can determine the factors that influence the Jakarta Islamic Index (JII) in the long run. The time-series data used is monthly data from January 2011 to December 2018. The result of this research presents the macroeconomic variables affect JII in the long run. This has implications for JII stability depending on the exchange rate of the rupiah against the US dollar, the business cycle, inflation, economic growth, and interest rates. Exchange rates and business cycles have a negative relationship with JII. Meanwhile, interest rates, CPI and IPI have a positive relationship with JII. This research shows the macroeconomic factors from the business-cycle, which can be taken to be determined. It seems that this study might be a suggestion for investors in making wise decisions in investing. Furthermore, the government plays a very important role in maintaining the stability of Islamic stocks and the factors that influence them. In addition, strengthening monetary policy is needed due to the stock movements cannot be separated from the policy.
\end{abstract}

Keywords: Jakarta Islamic Index, sharia stock, business-cycle.

$\begin{array}{llll}\text { Received } & \text { Revised } & \text { Accepted } & \text { Published } \\ \text { February 17, 2020 } & \text { March 31, 2020 } & \text { March 31, 2020 } & \text { March 31, 2020 }\end{array}$

\section{INTRODUCTION}

Recently, stability and sustainable economic development is seen from a strong financial system. Efficiency in the financial system starts from long-term investment and increases monetary intermediation which contributes to the spread of monetary resources (Afshan, Sharif, Loganathan, \& Jammazi, 2018). The stock market is predicted to bring prosperity to a country's financial system.

Furthermore, stock prices are considered as an indicator that plays an important role in the country's economy (Antonakakis, Gupta, \& Tiwari, 2017). Stock prices are always experiencing fluctuations driven by macroeconomic variables. This also has an impact on other economic sectors which then becomes the consideration of investors in investing. Then, the business cycle is designed to provide an initial turning point in the business cycle. This can show the fluctuation of a country's economy. This movement of economic activity can show both the long term and the short term (Pandey, Patnaik, \& Shah, 2017).

Economic activity cannot be separated from changes in the business cycle. This condition also exists at the level of loans and investment which will react quickly to the economic downturn and recover slowly when the economic situation improves. In addition, policymakers play a very important role that can influence the time and effectiveness of policy reforms and government intervention (Lo, Chou, \& Tsui, 2019).

Business cycles can force companies to innovate by releasing new, more sophisticated products. Company progress can be demonstrated by digitizing programs, which continue to 
innovate so as not to be left behind by other companies. The ability of companies to invest is affected by the recession that occurred in the global financial crisis that occurred from 2007 to 2009. These consequences are very important for long-term competitiveness and economic growth (Silvestri, Riccaboni, \& Della Malva, 2018). More and more companies are engaged in the field of digitalization, making innovation as a defense base so as not to lose in competition.

Indonesia is well-known as the largest Muslim population in the world, making the Islamic economy a vital issue that needs to be developed. Then, the halal business market to the capital market began to intensify to attract foreign investors, especially from the Middle East (Albaity \& Mustafa, 2018). However, this very promising potential has not yet been utilized by stakeholders to innovate with more comprehensive sharia economic products. This is evidenced by the Islamic financial industry which only fulfills a market share of $8 \%$ as in Bank Indonesia's financial statements (Indonesia, 2018).

However, as a developing country, Indonesia is vulnerable to global events that will have an impact on uncertain economies (Raza, Shahzad, Tiwari, \& Shahbaz, 2016). The vulnerability of stock market movements is very closely related to the country's macroeconomic indicators and other important factors. This must be watched out for by investors in making investment decisions and the government as the monetary policymaker for policy decisions (Ghosh \& Kanjilal, 2016). Investors are expected to consider exchange rates in a variety of frequencies. Then, stock returns and regulators should be able to consider taking good policy steps to prevent financial risk (Mohamed Dahir, Mahat, Ab Razak, \& Bany-Ariffin, 2018).

On the other hand, the movement of the Jakarta Islamic Index is inseparable from the condition of the Indonesian economy. There are several things that need to be considered in several economies, the exchange rate of the rupiah against the US dollar, inflation, the business cycle, economic growth, and central bank interest rates. Every macroeconomic movement will affect Islamic stocks. Fluctuations in macroeconomic variables can be concluded as indicated by having an important role in sharia stock index movements, namely JII. This will be an important foundation for investors in making important decisions to invest their capital in the capital market.

This paper will examine sharia shares represented by the Jakarta Islamic Index in terms of influencing factors in the macroeconomy. This study aims to investigate the factors that can affect the Jakarta Islamic Index in the short and long term. Then, the existence of this research is expected to provide insight to investors in predicting future stock prices, and the government to increase investment by improving macroeconomic indicators in Indonesia.

\section{LITERATURE REVIEW}

Jakarta Islamic index is one of the sharia stock indexes in Indonesia. This is a collaboration between the Indonesia Stock Exchange and Danareksa Investment Management (Tandelilin, 2010). Since July 3, 2000, JII was developed to support the formation of the Islamic capital market and was launched in Jakarta on March 14, 2003. The JII mechanism mimics existing patterns in Malaysia which are then combined with conventional exchanges. 
Shares that enter into JII meet shariah criteria (Sutedi, 2011). There are many studies that discuss the relationship between stock movements with macroeconomic variables in several countries (Mohamed Dahir et al., 2018; Roubaud \& Arouri, 2018; Peng, Hu, Chen, Zeng, \& Yang, 2019; Tursoy \& Faisal, 2018).

Inflation is an increase in prices in general and continuously (Mankiw, 2009). This condition will have an impact on increasing the overall price of products. This also has an impact on increasing the company's revenue and costs. If the increase in production is higher than the increase in prices that can be enjoyed by the company, the company's profitability will decrease (Tandelilin, 2010). The real and financial sector is highly influenced by inflation due to the most important macroeconomic variables. There are several measures of inflation, one of them is the Consumer Price Index (CPI).

There are several studies that discuss the relationship between the Consumer Price Index (CPI) with stock prices. Research that states that the relationship between the two is negative (Bekhet \& Mugableh, 2012; Rusbariand \& et.al, 2012). This is indicated by the people who put aside investment for consumption. Then, conditions have an impact on increasing the cost of living of people and decreasing stock in the capital market. While research that states that the relationship between them is positive (Kuwomu \& Victor, 2011; Hosseini \& et.al, 2011; Hussin \& et.al., 2012; Kewal, 2012). The real consumption of the community decreases because the value of money held by the community also decreases. This has a domino effect on the rising prices of goods and services. Thus, the reduction in consumption by the community will have an impact on reducing company profits because they have to reduce production costs.

Furthermore, there is a positive impact on stock prices and inflation, i.e. monetary easing can stimulate the economy together with inflation which will have a positive impact on the rate of dividend growth. Further impact, a monetary expansion that suppresses bond returns will result in increased demand for equities (Antonakakis et al., 2017).

Bank Indonesia's interest rates or BI rates are policy rates that reflect the stance or monetary policy stance set by Bank Indonesia and announced to the public. The interest rate that is too high will affect the present value of the company's cash flow so that investment opportunities that exist will no longer be attractive. High-interest rates will also increase the cost of capital that must be borne by the company (Mishkin, 2008). This will have an impact on banking industry interest rates which also increased. This is supported by research (Kuwomu \& Victor, 2011; Hussin \& et.al., 2012), which states that interest rates have a negative effect on stocks. Furthermore, this condition will attract investors to invest or move their investments from stocks to the banking sector (deposits). Thus it will cause the stock index to decline.

Moreover, the composite leading indicator (CLI) is a business cycle that is one of the macroeconomic indicators. The business cycle is a wave of ups and downs of a country's economic activities. The wave of economic activity can be seen from the development of the amount of national production, price developments, and the development of employment opportunities (Caraiani \& Călin, 2019). Based on this theory the relationship of the business cycle to the Islamic stock index is positive. If the business cycle relationship increases, the Islamic stock index will increase and vice versa. In research (Chen \& Hwang, 2019) 
macroeconomic variables are correlated to estimate the business cycle, stock returns are something that will be obtained in the future.

There are several studies that discuss the exchange rate of money on stock prices. One of them is a study (Afshan et al., 2018) that investigates the relationship between stock prices and exchange rates using the wavelet approach. The results of this study confirm the existence of a long-term relationship, moreover strong coherence dominates the share price to the exchange rate in the period 8-16 and 16-32 weeks. The most interesting thing is the twoway causality between the exchange rate and stock prices in the long run. Then, in research (Mohamed Dahir et al., 2018) shows that the relationship between the exchange rate and stock returns, in the long run, is positive in Brazil and Russia, whereas in India the relationship between the two is negative.

Indicators of a country's economic growth rate can be seen through the IPI (Industry Production Index). Furthermore, IPI can be considered by investors in determining the companies that are targeted for investment. The positive relationship between IPI and stock prices is presented by (Hosseini \& et.al, 2011; Hussin \& et.al., 2012; Bekhet \& Mugableh, 2012). The share price will be affected by an increase in the IPI, which will have an impact on the company's profits.

\section{METHOD}

This study uses secondary data from Bank Indonesia, BPS, the Indonesia Stock Exchange, Bank Indonesia database, and OECD database. Then, this study uses time-series data from January 2011 to December 2018. These data are then processed using the Eviews 9 application.

The data used are Jakarta Islamic Index (JII) sharia stock index, Industrial Production Index (IPI) data, Consumer Price Index (CPI) data, Rupiah exchange rate against US\$ (KURS), BI Rate, and Composite Leading Indicator (CLI). In addition, to facilitate data processing, KURS is transformed into a natural logarithm (Ln).

This research uses quantitative methods that are descriptive. Vector Autoregression (VAR) analysis is used when the data used is stationary at the level. However, if the data is not stationary at the level, the level is continued by using the first difference. An analysis tool of advanced stationary data at the first difference level using the Vector Error Correction Model (VECM) (Gujarati \& Porter, 2009). Furthermore, VAR analysis can describe data, forecasting, structural inference, and policy analysis through Forecasting, Impulse Response Function (IRF), Forecast Error Variance Decomposition (FEVD), and Granger Causality Test. The VAR general equation model is as follows:

$$
y_{t}=A_{0}+A_{1} y_{t-1}+A_{2} y_{t-2}+. .+A_{p} y_{t-p}+\varepsilon_{t}
$$

$\mathrm{y}_{\mathrm{t}}$ : vector sized (n.1) containing $\mathrm{n}$ variables contained in a VAR model

$\mathrm{A}_{0}$ : intercept vector sized (n.1)

$\mathrm{A}_{1}$ : coefficient matrix or size parameter (n.n) for each $\mathrm{i}=1,2, \ldots, \mathrm{p}$

$\varepsilon_{\mathrm{t}}$ : error vector sized (n.1)

Moreover, the Vector Error Correction Model (VECM) is a form of VAR that is the most restricted. This additional restriction is done because the form of data is not stationary at the level of level, and there is a cointegration relationship, the VAR model must be combined 
with the VECM model. Furthermore, in VECM there is the speed of adjustment from short to long term. This serves as an approach for estimating long-term and short-term relationships in one other time-series data (Gujarati \& Porter, 2009). Generally, The VECM model is as follows:

$$
\Delta y_{t}=\mu_{0 x}+\mu_{1 x}+\Pi_{x} y_{t-1}+\Delta y_{t-i}+\varepsilon_{t}
$$

$\mathrm{y}_{\mathrm{t}}$ : vector that contains the variables analyzed in the study

$\mu_{0 x}$ : intercept vector

$\mu_{1 \mathrm{x}}$ : regression coefficient vector

$\mathrm{t}$ : time trend

$\Pi_{\mathrm{x}}: \alpha x \beta$ 'where $\mathrm{b}^{\prime}$ contains the long-term cointegration equation

$\mathrm{y}_{\mathrm{t}}-1$ : in-level variable

$\Gamma_{\mathrm{ix}}$ : regression coefficient matrix

k-1: VECM order from VAR

\section{RESULT \& DISCUSSION}

The stationarity test is the most important step in analyzing time series data to see whether there is a root unit contained between variables so that the relationship between variables in the equation becomes valid. This stationarity test is performed on all variable time-series data used in VAR analysis.

Unit root testing in this research model is based on the Augmented Dickey-Fuller (ADF) test at the level. This test is used to determine whether a series has a unit root or not, with a comparison between ADF t-statistic values and ADF tables. If the absolute value of the t-statistic in the ADF test is smaller than the critical value of the ADF in a table with a certain level of significance, then the time series data is not stationary.

Table 1. Result of Unit root test in Level

\begin{tabular}{lccccl}
\hline \multirow{2}{*}{ Variables } & \multirow{2}{*}{$\begin{array}{c}\text { ADF t- } \\
\text { statistic }\end{array}$} & \multicolumn{3}{c}{ MacKinnon Critical Value } & Explanation \\
& -2.404246 & -3.500669 & -2.892200 & -2.583192 & Not Stationary \\
JII & -0.891711 & -3.500669 & -2.892200 & -2.583192 & Not Stationary \\
Ln_kurs & -1.328867 & -3.501445 & -2.892536 & -2.583371 & Not Stationary \\
BI RATE & -2.105207 & -3.500669 & -2.892200 & -2.583192 & Not Stationary \\
CPI & -1.879658 & -3.502238 & -2.892879 & -2.583553 & Not Stationary \\
CLI & -0.523217 & -3.502238 & -2.89288 & -2.583553 & Not Stationary \\
IPI & & & & & \\
\hline
\end{tabular}

Based on the results of the unit root test at the sixth level looks at non-stationary variables. This is indicated by the absolute value of the ADF statistic obtained by all variables smaller than the critical value of MacKinnon. Furthermore, data that are not stationary will produce spurious regression, which is a regression that describes the relationship between two or more variables that appear statistically significant but are not, so that it can produce misleading in research on an economic phenomenon that is happening. Furthermore, unit root testing of all variables is continued by conducting unit root tests at the first difference level. 
Table 2: Result of Unit root test in First Difference

\begin{tabular}{|c|c|c|c|c|c|}
\hline \multirow{2}{*}{ Variables } & \multirow{2}{*}{$\begin{array}{l}\text { ADF t- } \\
\text { statistic }\end{array}$} & \multicolumn{3}{|c|}{ MacKinnon Critical Value } & \multirow{2}{*}{ Explanation } \\
\hline & & $1 \%$ & $5 \%$ & $10 \%$ & \\
\hline JII & -8.779391 & -3.501445 & -2.892536 & -2.583371 & Stationary \\
\hline Ln_kurs & -10.30980 & -3.501445 & -2.892536 & -2.583371 & Stationary \\
\hline BI RATE & -6.378984 & -3.501445 & -2.892536 & -2.583371 & Stationary \\
\hline CPI & -9.616374 & -3.501445 & -2.892536 & -2.583371 & Stationary \\
\hline CLI & -5.199650 & -3.502238 & -2.892879 & -2.583553 & Stationary \\
\hline IPI & -12.770560 & -3.502238 & -2.892879 & -2.583553 & Stationary \\
\hline
\end{tabular}

Testing the root unit at the first difference level shows that all data is stationary. This is indicated by the absolute value of the ADF statistic that is greater than the MacKinnon Critical value at the critical value of $1 \%, 5 \%$, and $10 \%$. In addition, the variable to be estimated in this study is stationary to the same degree, at the degree of integration of one.

Table 3. Result of Lag Optimal

\begin{tabular}{cc}
\hline Lag & AIC \\
\hline 0 & 26.55471 \\
1 & 13.90426 \\
2 & 11.23161 \\
3 & $11.03748^{*}$ \\
\hline
\end{tabular}

The table presents that the optimal interval that will be used in the VECM model is lag 3. This is based on determining the optimal lag using the Akaike Information Criterion (AIC) criteria which shows the results of lag 3. Optimal lag testing is useful to eliminate the autocorrelation problem in the VAR system used as a VAR stability analysis. This can be expected to eliminate the problem of autocorrelation.

Table 4. Result of Johansen Cointegration Test Trace Statistic

\begin{tabular}{ccccc}
\hline $\begin{array}{c}\text { Hypothesized } \\
\text { No. of CE(s) }\end{array}$ & Eigenvalue & $\begin{array}{c}\text { Trace } \\
\text { Statistic }\end{array}$ & $\begin{array}{c}0.05 \text { Critical } \\
\text { Value }\end{array}$ & Prob.** \\
\hline None $*$ & 0.376339 & 114.7760 & 95.75366 & 0.0013 \\
At most 1 * & 0.282746 & 71.33835 & 69.81889 & 0.0376 \\
At most 2 & 0.195627 & 40.76437 & 47.85613 & 0.1963 \\
At most 3 & 0.108942 & 20.73665 & 29.79707 & 0.3743 \\
At most 4 & 0.072196 & 10.12488 & 15.49471 & 0.2713 \\
At most 5 & 0.034509 & 3.230891 & 3.841466 & 0.0723 \\
\hline
\end{tabular}

.Table 5. Result of Johansen Cointegration Test Max-Eigen Statistic

\begin{tabular}{ccccc}
\hline $\begin{array}{c}\text { Hypothesized } \\
\text { No. of CE }(\mathrm{s})\end{array}$ & Eigenvalue & $\begin{array}{c}\text { Max-Eigen } \\
\text { Statistic }\end{array}$ & $\begin{array}{c}\text { 0.05 Critical } \\
\text { Value }\end{array}$ & Prob.** \\
\hline None $*$ & 0.376339 & 43.43765 & 40.07757 & 0.0202 \\
At most 1 & 0.282746 & 30.57399 & 33.87687 & 0.1179 \\
At most 2 & 0.195627 & 20.02771 & 27.58434 & 0.3392 \\
At most 3 & 0.108942 & 10.61177 & 21.13162 & 0.6859 \\
\hline
\end{tabular}




\begin{tabular}{lllll}
\hline At most 4 & 0.072196 & 6.893994 & 14.26460 & 0.5018 \\
At most 5 & 0.034509 & 3.230891 & 3.841466 & 0.0723 \\
\hline
\end{tabular}

Based on the above table, it can be seen that there are two values of trace statistic, greater critical value with a significance level of 5\%. This states the null hypothesis that no cointegration is rejected and alternative hypotheses which state that there is cointegration cannot be rejected. Then, the next table explains that there is a Max-Eigen statistical value that is greater than the critical value with a probability of 5\%. From the results of these two tables indicate that between JII movements, exchange rates, interest rates, CLI, CPI, and IPI have a relationship of stability or balance and similarity of movement in the long run. This condition can also be interpreted that in each short-term period all variables tend to adjust, to achieve long-term equilibrium.

Table 6. Result of Granger Causality

\begin{tabular}{lc} 
Null Hypothesis: & Prob. \\
\hline LN_KURS does not Granger Cause JII & 0.1913 \\
\hline JII does not Granger Cause LN_KURS & 0.0168 \\
\hline IPI does not Granger Cause JII & 0.1558 \\
\hline JII does not Granger Cause IPI & 0.4495 \\
\hline CPI does not Granger Cause JII & 0.7724 \\
\hline JII does not Granger Cause CPI & 0.6785 \\
\hline CLI does not Granger Cause JII & 0.0187 \\
\hline JII does not Granger Cause CLI & 0.2540 \\
\hline BI_RATE does not Granger Cause JII & 0.8680 \\
\hline JII does not Granger Cause BI_RATE & 0.2072 \\
\hline IPI does not Granger Cause LN_KURS & 0.8130 \\
\hline LN_KURS does not Granger Cause IPI & 0.1383 \\
\hline CPI does not Granger Cause LN_KURS & 0.0046 \\
\hline LN_KURS does not Granger Cause CPI & 0.1493 \\
\hline CLI does not Granger Cause LN_KURS & 0.0024 \\
\hline LN_KURS does not Granger Cause CLI & 0.1448 \\
\hline BI_RATE does not Granger Cause LN_KURS & 0.2259 \\
\hline LN_KURS does not Granger Cause BI_RATE & 0.5442 \\
\hline CPI does not Granger Cause IPI & 0.9894 \\
\hline IPI does not Granger Cause CPI & 0.9537 \\
\hline CLI does not Granger Cause IPI & 0.7566 \\
\hline IPI does not Granger Cause CLI & 0.2849 \\
\hline BI_RATE does not Granger Cause IPI & 0.6055 \\
\hline IPI does not Granger Cause BI_RATE & 0.2262 \\
\hline CLI does not Granger Cause CPI & 0.2958 \\
\hline CPI does not Granger Cause CLI & 0.8432 \\
\hline BI_RATE does not Granger Cause CPI & 0.8949 \\
\hline CPI does not Granger Cause BI_RATE & \\
\hline BI_RATE does not Granger Cause CLI & 0.165 \\
\hline
\end{tabular}


Granger causality test results show that there is no two-way relationship between variables. The table shows a direct relationship, JII affects Ln_KURS (0.0168), CLI affects JII (0.0187), CPI affects Ln_KURS (0.0046), CLI affects Ln_KURS (0.0024), BI rate affects CPI (0.0491), CLI affects BI rate (0.0553).

Table 7: Result of VECM long-term

\begin{tabular}{lcc}
\hline \multicolumn{1}{c}{ Variables } & Coefficient & t-statistic \\
\hline JII(-1) & 1.000000 & \\
LN_KURS(-1) & -746.1921 & $-5.16092 * * *$ \\
BI_RATE(-1) & 30.53576 & $3.35822 * * *$ \\
CLI(-1) & -19.89542 & $-1.77722 * *$ \\
CPI(-1) & 1.762003 & $2.12973 * *$ \\
IPI(-1) & 4.978266 & $2.51910 * * *$ \\
C & 7307.373 & \\
\hline
\end{tabular}

The VECM test results table presents that the exchange rate of the rupiah against the US dollar (KURS) significantly affects JII and the relationship between the two is negative. Then, this variable most influences the JII, with an indication that every KURS rises by 1 percent, then JII will decrease by 746.1921 percent. (Rusbariand \& et.al, 2012) explained the same thing in his research, that the rupiah exchange rate had a significant negative effect on JII. Furthermore, commodity prices, which became the basic ingredients of production, increased, triggering the weakening of the rupiah against US\$. The continued impact of this situation is that the profit received by the company will decrease due to increased production costs, the company will lose investors because of the decline in the distribution of stock dividends and also result in a decrease in share prices at the company.

It can be interpreted that the exchange rate of the rupiah against US\$ is one of the factors that influence the movement of JII. This can be caused by companies incorporated in the Islamic stock market using imported goods as their raw materials. This condition makes the company's stock price affected by the shift of the rupiah exchange rate (Yao, 2019).

On the other hand, interest rates that have a significant positive relationship with JII. An increase in interest rates by $1 \%$ will increase JII by $30,53576 \%$, this also applies vice versa. Although the relationship between the two is different from positive findings (Kuwomu \& Victor, 2011; Hussin \& et.al., 2012) which states that interest rates have a significant negative effect on stock prices. However, this indicates that interest rates are not one of the sharia instruments, but JII's movements are inseparable from interest rates, especially when investors will invest. One of the qualification of Sharia firm is limitation of having funding form loans. It seems that Islamic capital market is saver than Conventional Capital Market. Despite, the investors are also still comparing the benefits of investment in the Islamic capital market with conventional. Thus, interest rates remain a consideration for investing for Muslim investors and it is more safety than conventional capital market.

Furthermore, the CLI business cycle on JII has been proven to have a significant but negative effect. Every one percent increase in the business cycle will reduce 19.89542 
percent of the Jakarta Islamic Index. This can be caused by the uncertainty of financial market conditions related to the uncertainty of rising interest rates. This is contrary to research (Caraiani \& Călin, 2019) which states that the wave of economic activity can be seen from the development of the amount of national production, price development, and the development of employment opportunities.

As aforementioned, the synchronization of business cycles will not be separated from the presence of foreign investment. The development of technology is present causing the exchange rate to move down along with the business cycle because the incoming foreign investment is very high. Similarly, if foreign investment entering a country is low, the exchange rate will strengthen and the business cycle will increase (Yao, 2019).

In addition, Allah SWT said in Al-Quran that concerning the investment for financial planning in the future.

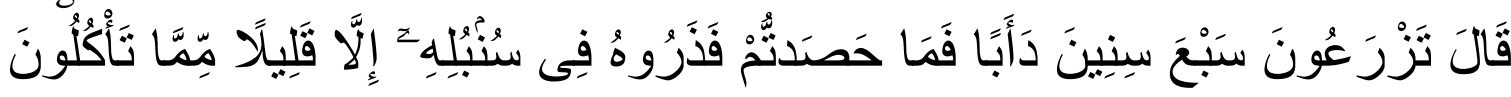

He said, 'You shall sow seven years after your wont; what you have harvested leave in the ear, excepting a little whereof you eat. (Yusuf: 47)

This verse explain about investment and how to manage it nowadays and for future. Hence, Allah SWT gives a fruitful explanation for taking decision in investment.

The results of long-term VECM estimates on the consumer price index show a positive and significant relationship. Every CPI increases by $1 \%$, JII will experience an increase of $1.762003 \%$. The same thing applies when there is a decrease in CPI, JII will experience a decrease. The results of this study are supported by (Kewal, 2012) which states that there is a positive and significant influence between inflation and JII. It seems that monetary easing can stimulate the economy together with inflation. Furthermore, investment returns obtained by investors will be reduced because of rising stocks. This is caused by increased inflation which will have an impact on the reduced level of real income earned. Hence, if inflation decreases in a country, there will be a decrease in stock prices because the risk of purchasing power of money and the risk of decreasing real income also decreases.

However, this study contradicts the research (Rusbariand \& et.al, 2012; Bekhet \& Mugableh, 2012) which explains that when inflation occurs it will have an impact on reducing or decreasing customer demand resulting in decreased company profits. This condition makes investors more alert and immediately shifts their capital to other companies that have greater profit opportunities or invests in savings or time deposits. This will cause the company's shares to decline.

It is known that there is a significant positive effect between IPI on JII. An increase in IPI of one percent will cause an increase in JII of 4.978266 percent. This research is supported by the results of research (Beik \& Fatmawati, 2014), which states that the impact of a positive relationship between IPI on JII is the company's profit. Furthermore, the real sector will experience an increase, the company's performance will also experience the same thing. This condition will trigger an increase in share prices because many companies that enter the stock exchange have a positive performance. Therefore, there is a strong correlation between the performance of the real sector and the price index on the Islamic stock market.

Figure 2 below represents the results of the Impulse Response Function (IRF), which can be seen in the picture that shows the shock that occurs at the exchange rate (Ln_KURS). 
JII responded positively and experienced a sharp increase in the third month. Then, it fluctuates but tends to be stable until the end of the observation period. Meanwhile, shocks to the IPI responded negatively and experienced a sharp decline in the first 3 months. Similar to IPI, shocks to the CPI were responded negatively by JII, the shock that occurred in these two variables was relatively stable until the end.

Figure 1: Result of Impulse Response Function (IRF)
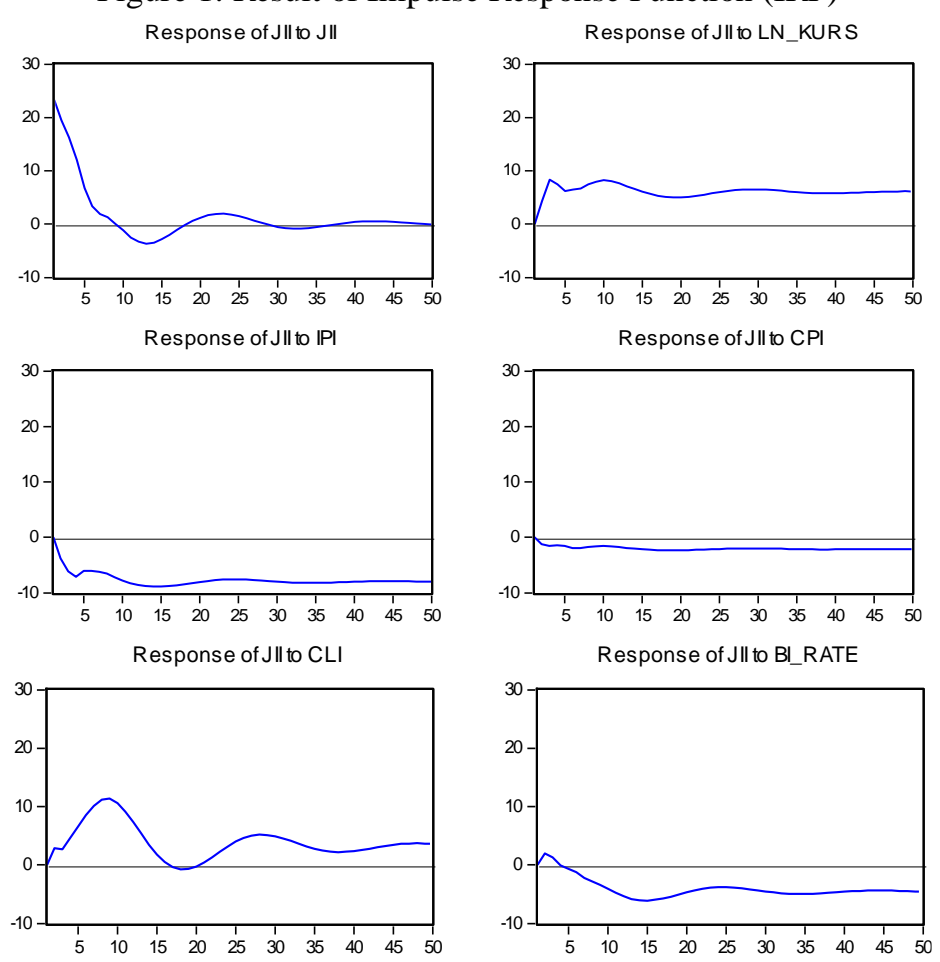

In addition, the shock on CLI responded positively by JII, even though it was responded negatively in the 17th month to the next 3 months. Conditions occur because there is a sharp decline starting from the 9th month until the 20th month. At the end of the period, CLI tends to be stable and respond positively, even though it has fluctuated.

Shocks to interest rates responded positively by JII in the first 3 months. However, it continued to decline and responded negatively, especially in the 15th month. Furthermore, again increased slightly in the next 10 months. In the 26th month back down, these shocks tend to be stable until the 50th month.

On the other hand, Forecast Error Variance Decomposition (FEVD) results show that JII in the first month contributed $100 \%$ JII index diversity. It gradually decreases until the end of the observation period. Then, IPI is the variable with the biggest contribution to the diversity of JII and continues to increase until the 50th period of $34.27 \%$. This shows that increased economic growth will be able to increase the diversity of JII.

Furthermore, the second largest variable contributing to JII diversity is the exchange rate against the US dollar. This variance contributed 22.10 percent at the end of the period. This condition explains that the stability of the rupiah exchange rate against the US dollar is very important because it contributes quite a lot. Similarly, interest rates and CPI continue to increase, each variance contributes almost $11 \%$ to interest rates, while CPI 2.33 percent on 
the diversity of JII. This condition can show that the benefits of investing in the Islamic capital market with conventional money markets are still a comparison to determine investment.

As with the fluctuating CLI, it increased very sharply at the beginning of the period. However, in the 15th period began to decline until the end of the period. CLI contributes $13.41 \%$ to JII diversity. This indicates that the business cycle is fluctuating due to pressure from interest rates and rising inflation.

\section{CONCLUSION}

This study shows that Indonesia's macroeconomic effects the Jakarta Islamic Index in the long run. In the long run, there are two variables, namely the exchange rate and the business cycle which shows a significant negative relationship. Meanwhile, interest rates, CPI, and IPI have a positive relationship and significantly influence the JII.

Furthermore, JII responds to the shock or shock to all observed macroeconomic variables before achieving stability using the IRF results. These results indicate that there are differences in time to reach a stable condition for each variable. JII achieves stability the fastest when it responds to interest rate shocks and CPI. Meanwhile, the variable with a high level of fluctuation is CLI, because the shock towards JII looks unstable. Furthermore, each variable has a different contribution to the diversity of JII, which can be seen from the results of the FEVD analysis. At the end of the observation period, the variable that contributed the most was IPI, while the variable which contributed the least was CPI.

The government plays a very important role as a policymaker and can intervene if necessary. This condition is intended for an economy that grows optimally with all the advantages and disadvantages. Meanwhile, investors can predict stability in order to make decisions in investing wisely. In addition, the need for portfolio diversification in preventing investment failures.

Future research is expected to compare the conventional capital market and the Islamic capital market. It can be a consideration for the investor for taking a decision in investment, and expanding year of research is needed which is a long-term decision in investment.

\section{REFERENCES}

Afshan, S., Sharif, A., Loganathan, N., \& Jammazi, R. (2018). Time-frequency causality between stock prices and exchange rates: Further evidences from cointegration and wavelet analysis. Physica A: Statistical Mechanics and Its Applications, 495, 225244.

Albaity, M., \& Mustafa, H. (2018). International and macroeconomic determinants of oil price: evidence from gulf cooperation council countries. International Journal of Energy Economics and Policy, 8(1), 69-81.

Antonakakis, N., Gupta, R., \& Tiwari, A. K. (2017). Has the correlation of inflation and stock prices changed in the United States over the last two centuries? Research in International Business and Finance, 42(April), 1-8.

Beik, I. S., \& Fatmawati, S. (2014). Effect of International Sharia Stock Price Index and Macroeconomic Variables on the Jakarta Islamic Index. Al-Iqtishad, 155-178. 
Bekhet, H., \& Mugableh, M. (2012). Investigating Equilibrium Relationship between Macroeconomic Variables and Malaysian Stock Market Index through Bounds Test Approach. International Journal of Economics and Finance.

Caraiani, P., \& Călin, A. C. (2019). The impact of monetary policy shocks on stock market bubbles: International evidence. Finance Research Letters, (October 2018), 1-8.

Chen, J. L., \& Hwang, H. (2019). Business cycle, expected return and momentum payoffs. Finance Research Letters, 29(February), 83-89.

Ghosh, S., \& Kanjilal, K. (2016). Co-movement of international crude oil price and Indian stock market: Evidences from nonlinear cointegration tests. Energy Economics, 53(2016), 111-117.

Gujarati, D. N., \& Porter, D. C. (2009). Basic Econometrics (5th ed.). New York: McGrawHill/Irwin.

Hosseini, S., \& et.al. (2011). The Role of Macroeconomic Variables on Stock Market Index in China and India. International Journal of Economics and Finance.

Hussin, M., \& et.al. (2012). Macroeconomic Variable and Malaysian Islamic Stock Market: A Time Series Analysis. Journal of Business Studies Quarterly, 1-13.

Indonesia, B. (2018). Laporan Keuangan Tahunan Bank Indonesia. Jakarta: Bank Indonesia.

Kewal, S. (2012). Effects of Inflation, Interest Rates, Exchange Rates, and GDP Growth on the Composite Stock Price Index. Jurnal Economia, 53-64.

Kuwomu, J., \& Victor, O. (2011). Macroeconomic variables and Stock Market Returns: Full Information Maximum Likelihood Estimation. Journal of Finance and Accounting.

Lo, K. T., Chou, T. S., \& Tsui, S. (2019). The asymmetric behavior of household consumption under the business cycle. North American Journal of Economics and Finance, $(\mathrm{xxxx}), 1-13$.

Mankiw, G. N. (2009). Macroeconomics. New York: Worth Publishers.

Mishkin F. S. (2004). The economics of money, banking, and financial markets. Mishkin Frederic-Addison Wesley Longman.

Mohamed Dahir, A., Mahat, F., Ab Razak, N. H., \& Bany-Ariffin, A. N. (2018). Revisiting the dynamic relationship between exchange rates and stock prices in BRICS countries: A wavelet analysis. Borsa Istanbul Review, 18(2), 101-113.

Pandey, R., Patnaik, I., \& Shah, A. (2017). Dating business cycles in India. Indian Growth and Development Review, 10(1), 32-61.

Peng, W., Hu, S., Chen, W., Zeng, Y. feng, \& Yang, L. (2019). Modeling the joint dynamic value at risk of the volatility index, oil price, and exchange rate. International Review of Economics and Finance, 59 (September 2018), 137-149.

Raza, N., Shahzad, S. J. H., Tiwari, A. K., \& Shahbaz, M. (2016). Asymmetric impact of gold, oil prices and their volatilities on stock prices of emerging markets. Resources Policy, 49, 290-301.

Roubaud, D., \& Arouri, M. (2018). Oil prices, exchange rates and stock markets under uncertainty and regime-switching. Finance Research Letters, 27(February), 28-33.

Rusbariand, \& et.al. (2012). Analysis The influence of the inflation rate, world oil prices, world gold prices, and the rupiah exchange rate on the movement of JII on the IDX. Proceedings of the National Seminar.

Silvestri, D., Riccaboni, M., \& Della Malva, A. (2018). Sailing in all winds: Technological search over the business cycle. Research Policy, 47(10), 1933-1944.

Sutedi, A. (2011). Good Corporate Governance. Jakarta : Sinar Grafika.

Tandelilin, E. (2010). Portfolio and Investment Theories and Applications. Yogyakarta: Kanisius. 
Tursoy, T., \& Faisal, F. (2018). The impact of gold and crude oil prices on stock market in Turkey: Empirical evidences from ARDL bounds test and combined cointegration. Resources Policy, 55 (November 2017), 49-54.

Yao, W. (2019). International business cycles and financial frictions. Journal of International Economics, 118, 283-291 